\title{
Temperature dependence of oxygen respiration, nitrogen mineralization, and nitrification in Arctic sediments
}

\author{
Bo Thamdrup*, Swantje Fleischer \\ Max Planck Institute for Marine Microbiology, Celsiusstr. 1, D-28359 Bremen, Germany
}

\begin{abstract}
The temperature dependence of oxic mineralization processes in perennially cold coastal sediments from Arctic Svalbard, Norway, was determined in short-term incubations at -1 to $44^{\circ} \mathrm{C}$ and compared to similar incubations with warm temperate sediment. For oxygen respiration, nitrogen mineralization, and nitrification, adaptations to low temperature were evident with the microbial communities from Svalbard. Oxygen respiration rates showed the same temperature dependence at all sites around Svalbard, with relatively high rates at $0^{\circ} \mathrm{C}$ and a linear $3-$ to 4 -fold increase from $0^{\circ} \mathrm{C}$ to a mean optimum temperature of $19.2^{\circ} \mathrm{C}$, whereas rates in the temperate sediment were close to zero at $0^{\circ} \mathrm{C}$ and had optimum at 30 to $40^{\circ} \mathrm{C}$. The temperature dependence of nitrogen mineralization was comparable to that of oxygen respiration, and C:N mineralization ratios in the Svalbard sediments were stable at 6 to 8 below $20^{\circ} \mathrm{C}$. Thus, low temperature did not affect carbon and nitrogen mineralization differentially. The most prominent adaptation to low temperatures was observed for nitrification, which had a mean optimum temperature of $14.0^{\circ} \mathrm{C}$ at Svalbard and decreased rapidly in rate at higher temperatures. In the warm temperate sediment the nitrification optimum was near $40^{\circ} \mathrm{C}$. The catalytic efficiency of the nitrifying communities from Svalbard, at their in situ temperature, was as high as that reported for communities from temperate regions. This implied that thermal adaptation fully compensated for direct temperature effects on this metabolism.
\end{abstract}

KEY WORDS: Benthic aerobic communities - Thermal adaptation - $Q_{10}$. Optimum temperature C:N mineralization ratio

\section{INTRODUCTION}

Temperature is recognized as an important contributor to the seasonal variation in rates of microbial processes in sediments (e.g. Pamatmat 1971, Jørgensen \& Sørensen 1985, Westrich \& Berner 1988, Banta et al. 1995). Temperature has a direct influence on reaction kinetics, but metabolic rates of bacterial communities may also be influenced by temperature-dependent changes or changes in physiology or community structure. Thus, for benthic nitrate reduction, nitrification, and oxygen respiration, seasonal covariation of optimum temperatures or $Q_{10}$ values with in situ temperature implies a thermal adaptation of the populations

\footnotetext{
- Present address: Institute of Biology, Odense University,
} DK-5230 Odense M, Denmark. E-mail: bot@biology.ou.dk that catalyze these processes in temperate sediments (King \& Nedwell 1984, Henriksen \& Kemp 1988, Thamdrup et al. 1998). Likewise, adaptive seasonal changes have been observed in the temperature characteristics of growth of bacterioplankton (Sieburth 1967, Li \& Dickie 1987).

For high-latitude waters it has been hypothesized that - and debated whether - the activity of bacterioplankton is more strongly inhibited by low temperatures than is primary production, which could lead to enhanced export from the photic zone to the sediment (Pomeroy \& Deibel 1986, Pomeroy et al. 1991, Rivkin et al. 1996). Such differential temperature effects on microbial processes have important implications for matter and energy flow. Whereas the pelagic communities have received some attention, little is known about the structure and function of benthic microbial communities at temperatures permanently around 
$0^{\circ} \mathrm{C}$, as found in the polar regions, nor is it clear to what extent low temperatures alter the balance between mineralization and burial of organic matter relative to warmer regions. Total benthic respiration rates in polar sediments may be as high as in temperate regions (Grebmeier \& McRoy 1989, Nedwell et al. 1993), which could indicate that the benthic microbial communities through adaptation fully compensate for the kinetic effects of low temperature. Investigations of the individual metabolic pathways are needed to test this hypothesis.

Studies of the temperature characteristics of mineralization pathways in polar benthic communities have mainly concentrated on sulfate reduction. For this process, both optimum temperatures and $Q_{10}$ values are lower in sediments from the polar regions than in temperate areas, and the temperature characteristics indicate predominantly psychrotolerant sulfate-reducing populations (Nedwell 1989, Isaksen \& Jørgensen 1996 Sagemann et al. 1998).

We have investigated the temperature characteristics of oxic mineralization processes in sediments from Svalbard, Arctic Norway. The fjords of southern Svalbard are characterized by an annual primary production which is comparable to that of many temperate shelf areas and by stable bottom water temperatures around $0^{\circ} \mathrm{C}$ (Eilertsen et al. 1989). The area is therefore well suited for investigations of benthic mineralization at low temperature. For comparison, experiments were also performed with sediment from a warm temperate site. Mineralization rates were determined both as oxygen respiration and nitrogen mineralization. Measurements of nitrification allowed the separation of oxygen consumption due to carbon and nitrogen oxidation, whereby the temperature dependence of C:N mineralization ratios could be quantified.

\section{METHODS}

Locations. Sediments were sampled in October 1995 from RV 'Jan Majen' in 3 Svalbard fjords: Hornsund (Sv2) and Van Mijenfjord (Sv3) on the west coast, and Storfjorden (Sv5) on the east coast of Spitzbergen Island. Water depths were 115 to $175 \mathrm{~m}$, and bottom water temperatures were $2.6,0.2$, and $-1.7^{\circ} \mathrm{C}$ at Sv2, Sv3, and Sv5, respectively. For each site, only small seasonal variations are expected, and the measured values should be close to the annual maximum (see also Eilertsen et al. 1989, Hulth et al. 1994) The surface sediment was fine brown silt at all stations.

Further sediment was collected in September 1996 at the tidal flat of Weddewarden (Ww) in the Weser estuary, Germany. At the time of sampling, noon at low tide, the surface sediment was $26^{\circ} \mathrm{C}$, but the tempera- ture was estimated to vary dielly between 15 and $30^{\circ} \mathrm{C}$ at this time of year. Seasonally, the temperature varies from 0 to $30^{\circ} \mathrm{C}$. The sediment consisted of fine silt and was covered by a film of diatoms.

Sediment retrieval and preincubation. A series of similar experiments was performed with slurries of oxic surface sediment. For the Svalbard stations, a set of undisturbed sediment cores of $9.6 \mathrm{~cm}$ diameter were obtained for each experiment with a multiple corer and stored at bottom water temperature. Air temperature was 0 to $2^{\circ} \mathrm{C}$ so that heating during retrieval was negligible. Within a few hours of retrieval, the upper 0.5 to $1 \mathrm{~cm}$ of sediment from 5 or 6 cores was collected, which corresponded to the oxic surface layer (R. N. Glud, O. Holby, F. Hoffmann \& D. E. Canfield unpubl.). The sediment was immediately passed through a $125 \mu \mathrm{m}$ sieve to remove fauna, shell debris, and occasional dropstones. The sieving also served to break up any aggregates in which anoxia could develop and removed less than $5 \%$ of the dry sediment matter. The sieved sediment was taken to a room thermostated to bottom water temperature $\pm 1^{\circ} \mathrm{C}$ and diluted 1.7 - to 17 -fold with bottom water in a glass bottle. To exclude an influence of bottom water bacteria on the experiments, the water was passed through a $0.2 \mu \mathrm{m}$ Nucleopore filter just before use. The slurry was kept in suspension by magnetic stirring and aerated for 1.5 to $16 \mathrm{~h}$. This step served to oxidize reduced inorganic species such as $\mathrm{Mn}^{2+}$ and $\mathrm{Fe}^{2+}$ and, thus, minimize abiotic or lithotrophic oxygen consumption. From the tidal flat of Weddewarden, the upper 2 to $3 \mathrm{~mm}$ was collected from $\sim 0.5 \mathrm{~m}^{2}$ of sediment. The sediment was handled as the Svalbard samples. Handling took place at $20^{\circ} \mathrm{C}$, and the resulting slurries were diluted 12 - to 30 -fold and aerated for 17 to $40 \mathrm{~h}$.

Incubations. In principle, the incubation procedure was similar to that previously used and discussed with temperate coastal sediment (Thamdrup et al. 1998). As demonstrated there, aerobic respiration rates are independent of oxygen concentration down to concentrations of a few micromoles per litre. Sieving and incubation in suspension excludes diffusive limitations to oxygen consumption as well as the development of anoxic microniches. The dilution of the sediment furthermore reduces the volume-specific oxygen consumption rates, resulting in practical incubation times.

Slurry was led into $13 \mathrm{ml}$ glass test tubes that were placed in a $185 \mathrm{~cm}$ long aluminum temperature gradient block (TGB) at ca $1.5^{\circ} \mathrm{C}$ intervals between -1 and $45^{\circ} \mathrm{C}$. Additional subsamples were immediately frozen for the general characterization of the slurry. The test tubes in the TGB were preincubated open for 0.75 to $1 \mathrm{~h}$, during which they were repeatedly shaken. This step served to equilibrate the slurry with the atmosphere at the higher temperatures where supersatura- 
tion with air would otherwise lead to bubble formation, disturbing the oxygen determination. The tubes were then sealed with butyl rubber stoppers without headspace to initiate incubation, and samples were taken from all temperatures for determination of initial oxygen concentrations. During the incubation, the slurry was kept in suspension by rocking the entire TGB around its longitudinal axis between $30^{\circ}$ and $150^{\circ}$ relative to vertical, at about $30 \mathrm{cpm}$. Stirring was aided by a glass bead in each tube.

For termination of the incubation, test tubes were transferred to ice water, centrifuged at $0^{\circ} \mathrm{C}$, and kept in ice water during sampling. Oxygen consumption from the supernatant between centrifugation and sampling was negligible due to the combined effects of low temperature and diffusive limitations in the sediment pellet. Five $\mathrm{ml}$ subsamples of the supernatant for $\mathrm{O}_{2}$ determination were withdrawn from just above the sediment pellet in $5 \mathrm{ml}$ all-glass syringes equipped with a stop cock and a $1 \mathrm{~mm}$ i.d. steel canula. The dead volume of the syringes was flushed and filled with $\mathrm{N}_{2}$ purged water just before sampling. The remaining supernatant was filtered through Whatman GF/F filters and frozen for analysis of nitrogen species.

Analysis. Oxygen was determined by the Winkler method (Grasshoff et al. 1983) by injecting the reagents into the glass syringes and titrating the entire volume. Blanks were $<5 \mu \mathrm{M}$ and the estimated relative standard deviation, RSD, $2 \%$. Nitrite was determined colorimetrically (RSD 1\%; Grasshoff et al. 1983), $\mathrm{NO}_{2}{ }^{-}$ $+\mathrm{NO}_{3}{ }^{-}$was determined by chemiluminescence after reduction to NO with $\mathrm{V}^{3+}$ (RSD 1\%; Braman \& Hendrix 1989), and the concentration of $\mathrm{NO}_{3}{ }^{-}$was found by difference. Ammonia was measured by flow injection with gas exchange and conductivity detection (RSD $2 \%$; Hall \& Aller 1992). Total reduced inorganic sulfur, $\mathrm{FeS}+\mathrm{FeS}_{2}+\mathrm{S}^{0}$, was determined in frozen samples by sulfide distillation with hot $\mathrm{Cr}^{2+}$ in $\mathrm{HCl}$ (Zhabina \& Volkov 1978).

Curve fitting. The Arrhenius function, Rate = $A \cdot \exp \left(-E_{\mathrm{a}} \cdot[R \cdot T]^{-1}\right)$, where $A$ is a constant, $E_{\mathrm{a}}$ the apparent activation energy, $R$ the gas constant, and $T$ absolute temperature, was fit to the data by non-linear regression using KaleidaGraph 3.0.4 (Abelbeck Software), which produced $E_{\text {a }}$ with a standard error estimate. From $E_{a}, Q_{10}$ for the temperature interval $T$ to $T+10 \mathrm{~K}$ was calculated as $Q_{10}=\exp \left\{E_{\mathrm{a}} \cdot 10 \mathrm{~K} \cdot[T \cdot(T\right.$ $\left.+10 \mathrm{~K}) \cdot R]^{-1}\right\}$. The Arrhenius function was used because it generally provided a good fit, and because it is the most widely used expression for the quantification of temperature dependence of bacterial processes in culture and nature, so that the resulting $E_{a}$ (or $Q_{1,0}$ ) enables a direct comparison to other studies. Other functions may provide better fits or mechanistically more correct descriptions of the effect of temperature on the processes (e.g. Ratkowsky et al. 1983, Li \& Dickie 1987, Stark 1996).

\section{RESULTS}

The temperature dependence of oxic mineralization processes was investigated in duplicate experiments at each station. In most experiments, 2 or 3 different incubation times were used to find the optimum time where, firstly, a significant oxygen consumption was observed at temperatures with low activity and, secondly, oxygen was not depleted at temperatures of high activity. The different incubation times further served as a control that rates did not change over time. Fig. 1 shows the results from one incubation time in each experiment. With the Svalbard sediments, the same general pattern of oxygen consumption was observed in all experiments independent of incubation time, which varied between 1 and $13 \mathrm{~h}$. The rate increased approximately 3 -fold in a linear manner from $0^{\circ} \mathrm{C}$ to a maximum at 17 to $20^{\circ} \mathrm{C}$ (average $19.2^{\circ} \mathrm{C}$; Table 1). The decrease above the optimum temperature was relatively small, and rates remained at $50 \%$ or more of the maximum rate.

Table 1. Optimum temperatures, apparent activation energies $\pm \mathrm{SE}$, and $Q_{10}$ for oxygen respiration in sediments from Arctic Svalbard (Sv2a, b, Sv3a, b and Sv5a, b) and Weddewarden (Wwa, b), Weser estuary, Germany

\begin{tabular}{|c|c|c|c|c|}
\hline Expt & $\begin{array}{l}\text { Incub. } \\
\text { time (h) }\end{array}$ & $\begin{array}{l}T_{\text {opt }} \\
\left({ }^{\circ} \mathrm{C}\right)\end{array}$ & 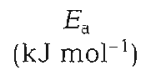 & $\begin{array}{c}Q_{10} \\
\left(0-10^{\circ} \mathrm{C}\right)\end{array}$ \\
\hline \multirow[t]{2}{*}{ Sv2a } & 6 & 19.9 & $40 \pm 3$ & 1.9 \\
\hline & 10 & - & $37 \pm 4$ & 1.8 \\
\hline \multirow[t]{3}{*}{ Sv2b } & 3 & 16.9 & $49 \pm 7$ & 2.1 \\
\hline & 5 & - & $45 \pm 3$ & 2.0 \\
\hline & 8 & - & $42 \pm 4$ & 1.9 \\
\hline \multirow[t]{3}{*}{ Sv3a } & 4 & 22.9 & $31 \pm 5$ & 1.6 \\
\hline & 8 & 19.9 & - & - \\
\hline & 13 & - & $36 \pm 4$ & 1.7 \\
\hline \multirow[t]{3}{*}{ Sv3b } & 3 & 16.9 & $42 \pm 5$ & 1.9 \\
\hline & 6 & 18.4 & $32 \pm 4$ & 1.6 \\
\hline & 8 & 19.9 & $34 \pm 2$ & 1.7 \\
\hline \multirow[t]{2}{*}{ Sv5a } & 5 & 19.9 & $40 \pm 5$ & 1.9 \\
\hline & 7 & 24.4 & - & - \\
\hline \multirow[t]{2}{*}{ Sv $5 b$} & 1 & 16.9 & $33 \pm 3$ & 1.7 \\
\hline & 2 & 15.4 & $42 \pm 7$ & 1.9 \\
\hline $\begin{array}{l}\text { Svalbard } \\
\text { average }\end{array}$ & & 19.2 & $39 \pm 5$ & 1.8 \\
\hline \multirow[t]{3}{*}{ Wwa } & 2 & 41.1 & $103 \pm 23$ & 4.9 \\
\hline & 4 & 35.1 & $67 \pm 11$ & 2.8 \\
\hline & 6 & - & $67 \pm 6$ & 2.8 \\
\hline Wwb & 2 & - & $59 \pm 13$ & 2.5 \\
\hline $\begin{array}{l}\text { Weddewarden } \\
\text { average }\end{array}$ & & 38.3 & $74 \pm 20$ & 3.3 \\
\hline
\end{tabular}




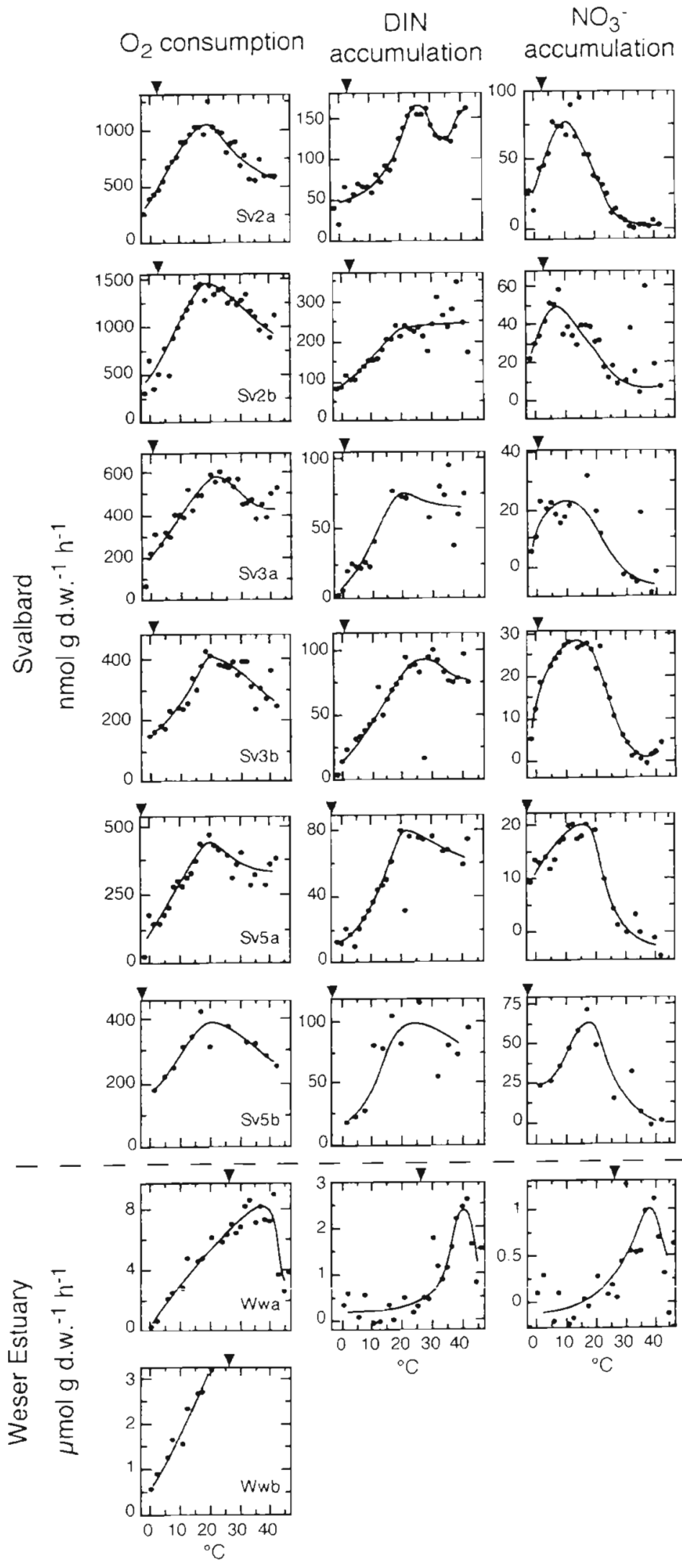

At temperatures below the optimum, the oxygen consumption rate was stable over the incubation times tested (data not shown). Only Expt Sv3b showed a marked decrease in rate with time, but as the relative decrease was similar at all temperatures $<20^{\circ} \mathrm{C}$, the relative temperature dependence did not change. In Expts Sv2b and Sv3a, a second maximum developed at 30 to $35^{\circ} \mathrm{C}$ with longer incubation times, after lag phases of $>3$ and $>8 \mathrm{~h}$, respectively, and eventually it covered the primary maximum (Fig. 2 and data not shown). Increasing activity in this temperature interval was not observed in any other experiments.

The German tidal flat sediment exhibited a quite different temperature response for oxygen consumption, with maximal rates at 30 to $40^{\circ} \mathrm{C}$ and an abrupt decrease above this (Fig. 1). From 0 to $20^{\circ} \mathrm{C}$ the rate increased 6 fold or more, i.e. twice as strongly as in the Svalbard sediments, and the total increase from $0^{\circ} \mathrm{C}$ to the optimum temperature was more than 10 -fold.

No effects of the varying degree of sediment dilution were observed. Thus, rates per gram sediment were similar in Sv5a and b with 9and 1.7 -fold dilution, respectively, and in the 2 Weddewarden experiments with 12 - and 30 fold dilution (Fig. 1).

Apparent activation energies, $E_{a r}$ for the individual incubations were obtained by fitting the Arrhenius expression to the data over the temperature range 0 to $15^{\circ} \mathrm{C}$ (Table 1 ). The resulting average $E_{a}$ was $39 \pm 5$ (SD) kJ $\mathrm{mol}^{-1}(\mathrm{n}=13$ ) for the Svalbard experiments and $74 \pm 20 \mathrm{~kJ} \mathrm{~mol}^{-1}(\mathrm{n}=4)$ for Weddewarden, which corresponded to $Q_{10}\left(0\right.$ to $\left.10^{\circ} \mathrm{C}\right)$ values of 1.8 and 3.3, respectively.

The temperature dependence of nitrogen mineralization was measured as the accumulation rate of dissolved inorganic nitrogen $\left(\mathrm{DIN}=\mathrm{NH}_{4}{ }^{+}+\mathrm{NO}_{2}{ }^{-}+\mathrm{NO}_{3}{ }^{-}\right)$. Typically $-50 \%$ of the ammonia in fine-grained sediments is adsorbed (Mackin \& Aller 1984) but, because of the high watersediment ratio in the slur-

Fig. 1 Temperature dependence of rates of oxygen consumption, accumulation of dissolved inorganic nitrogen (DIN), and accumulation of nitrate in sediments from Arctic Svalbard, Norway (Sv2, Sv3 and Sv5), and the temperate Weser estuary, Germany (WW). Duplicate experiments designated $a$ and $b$ are shown for each station. The in situ temperatures are indicated by an arrow above each frame 


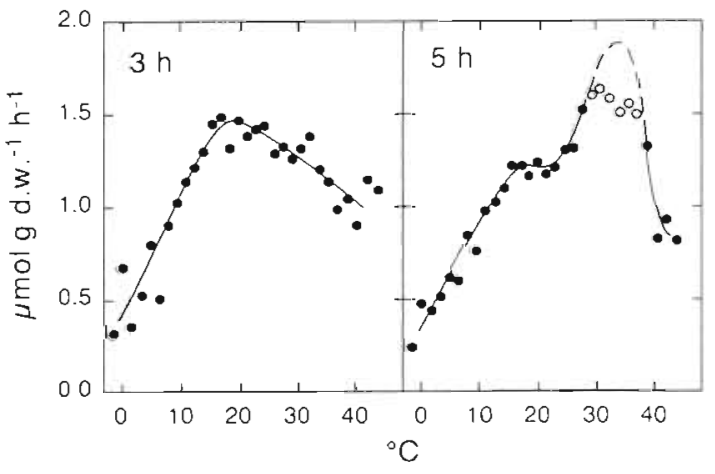

Fig. 2. Temperature dependence of oxygen consumption with 3 and $5 \mathrm{~h}$ incubations in Expt Sv2b. Due to oxygen depletion in the incubations between 30 and $40^{\circ} \mathrm{C}$ between 3 and $5 \mathrm{~h}$, only minimum rates could be calculated, as indicated by open symbols, and the dashed curve is hypothetical based on extrapolation

ries, adsorbed ammonia should contribute little to the inorganic combined nitrogen pool and was not included in the measurements. The temperature dependence of nitrogen mineralization showed some similarity to that of oxygen consumption at the Svalbard stations (Fig. 1). Thus, below $20^{\circ} \mathrm{C}$, nitrogen mineralization increased parallel to oxygen consumption. In most experiments, the rate levelled off around $20^{\circ} \mathrm{C}$ and tended to decrease at higher temperatures. During the brief Expt Sv5b the change in DIN concentration was small and the resulting rates were therefore rather scattered. Overall, however, these results were in good agreement with the other experiments. Also in the temperate sediment from Weddewarden high initial DIN levels and a short incubation resulted in scattered accumulation rates. Still, a markedly different temperature dependence than in the Svalbard sediments was evident, with an optimum at $40^{\circ} \mathrm{C}$. Initial ammonia concentrations were 10 to $25 \mu \mathrm{M}$ at Svalbard and $30 \mu \mathrm{M}$ at Weddewarden, and the concentration increased or remained constant in all incubations.

Nitrification, the production of $\mathrm{NO}_{2}^{-}$and $\mathrm{NO}_{3}{ }^{-}$, showed a distinctly different temperature dependence than that for oxygen consumption and nitrogen mineralization, with higher activity at lower temperatures at all Svalbard stations (Fig. 1). The activity increased 2to 3 -fold from $0^{\circ} \mathrm{C}$ to an optimum at 8 to $16^{\circ} \mathrm{C}$, mean $14.0^{\circ} \mathrm{C}$, above which the rate decreased rapidly. Little or no nitrification was measured above $30^{\circ} \mathrm{C}$. The product of nitrification was exclusively nitrate, as nitrite concentrations were always $\leq 1 \mu \mathrm{M}$ (data not shown). Below $10^{\circ} \mathrm{C}$ close to all of the produced DIN was found as nitrate, but this fraction decreased rapidly at higher temperatures. The Weddewarden sediment showed a distinctly different pattern as nitrification followed DIN accumulation and rates in- creased strongly with temperature to an optimum at 30 to $40^{\circ} \mathrm{C}$. Nitrate accounted for approximately $50 \%$ of the DIN produced in this sediment, the rest being ammonia. Due to the convex shape of the temperature dependency from $0^{\circ} \mathrm{C}$ to the optimum, it was not meaningful to fit nitrification rates from Svalbard to the Arrhenius function.

At a reaction stoichiometry of $1 \mathrm{NH}_{4}{ }^{+}$per $2 \mathrm{O}_{2}$, the oxidation of ammonia to nitrate by nitrifying bacteria accounted for up to $25 \%$ of oxygen consumption. Due to the different responses of nitrification and total oxygen consumption to temperature at the Svalbard stations, the oxygen consumption that was not coupled to nitrification, i.e. that coupled directly to carbon oxidation found by subtraction of oxygen consumed by nitrification from the measured oxygen consumption rates, showed a slightly higher temperature dependency than total oxygen consumption, with an increase of the apparent activation energy by approximately $10 \%$, whereas the optimum temperature did not change (data not shown).

There was no systematic variation in the ratio of nitrogen mineralization to oxygen consumption corrected for nitrification among sites or experiments. Fig. 3 shows the mean of these ratios from experiments Sv2a through Sv5a from Fig. 1. The ratio showed some scatter, particularly at low temperatures where both numbers had the largest relative errors. Still, below $20^{\circ} \mathrm{C}$ values were relatively constant at $1: 6-8$ and increased to $1: 4-5$ above $20^{\circ} \mathrm{C}$.

The content of total reducible inorganic sulfur, TRIS, in the sediments was $16.8,6.4$, and $4.4 \mu \mathrm{mol} \mathrm{g} \mathrm{g}^{-1} \mathrm{dry}$ wt at Sv2, Sv3, and Sv5, respectively. Separate analysis of $\mathrm{S}^{0}, \mathrm{FeS}$ and pyrite $\left(\mathrm{FeS}_{2}\right)$ showed that TRIS in the oxic surface sediment at all Svalbard sites almost exclusively consisted of pyrite (J. E. Kostka pers. comm.).

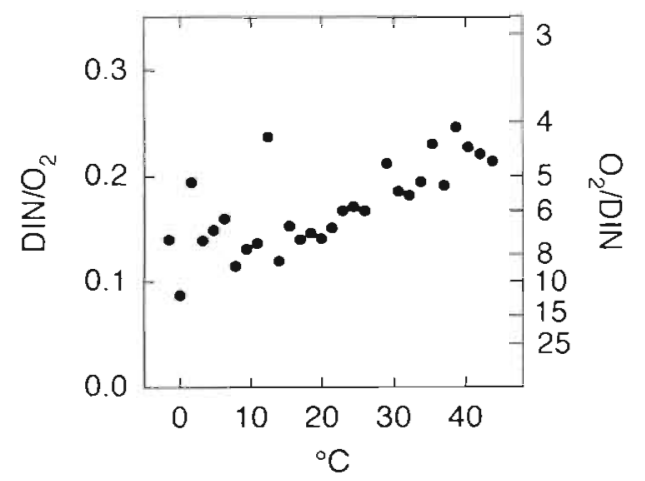

Fig. 3. Temperature dependence of the molar ratio of dissolved inorganic nitrogen (DIN) accumulation rates and oxygen consumption in Svalbard sediments. Oxygen consumption has been corrected for the contribution of nitrification. Mean of experiments Sv2a to Sv5a. DIN: $\mathrm{O}_{2}$ ratios corresponding to the $\mathrm{O}_{2}$ :DIN ratios are shown on the right axis 
Pyrite was the only reduced inorganic compound that was initially present in significant amounts in the oxic sediment used for the incubations. Oxidation rates of sedimentary pyrite in seawater at $22^{\circ} \mathrm{C}$ have been found to stabilize rapidly at $\leq 0.7 \% \mathrm{~d}^{-1}$ (Morse 1991). An oxidation rate of $0.7 \% \mathrm{~d}^{-1}$ and an oxygen:pyrite ratio of $15: 4$ for the complete oxidation of pyrite iron and sulfur result in an oxygen consumption of $9 \mathrm{nmol}$ $\mathrm{g}^{-1} \mathrm{~h}^{-1}$ for the sediment from Sv2 and less than half of this for Sv3 and Sv5. Although the temperature dependence of pyrite oxidation is not known, we can, based on this calculation, safely assume that the rate was insignificant for oxygen consumption at all temperatures, and conclude that the measured oxygen consumption was coupled to the oxidation of organic matter. Also, in earlier similar experiments, pyrite oxidation was insignificant for oxygen consumption (Thamdrup et al. 1998).

\section{DISCUSSION}

\section{Oxygen respiration}

The temperature responses were similar at all Svalbard stations implying a similar composition of the active aerobic communities and, hence, that the in situ temperature range of $4.5^{\circ} \mathrm{C}$ between Sv2 and Sv5 had no discernible effect on population structure. Compared to the temperate sediment from Weddewarden, however, adaptation to the low temperatures was evident from changes in both optimum temperature and in the relative increase in activity with temperature expressed by the $E_{\mathrm{a}}$ or $Q_{10}$ values. The optimum just below $20^{\circ} \mathrm{C}$ and high activity at $0^{\circ} \mathrm{C}$ at the Svalbard stations suggested that the aerobic community here was dominated by psychrotolerant bacteria $\left(T_{\min }<0^{\circ} \mathrm{C}\right.$, $T_{\text {opt }}>15^{\circ} \mathrm{C}$ ), whereas a dominantly mesophilic population was implied at Weddewarden. Strictly, however, the thermal classes refer to temperature dependence of growth, for which narrower limits and a lower optimum is typically found than for respiration (Harder \& Veldkamp 1971, Christian \& Wiebe 1974, Isaksen \& Jørgensen 1996). We can therefore not exclude the possibility that the Svalbard communities were actually dominated by psychrophilic bacteria that did not grow but continued to respire above $20^{\circ} \mathrm{C}$.

The induction of mesophilic activity after a lag phase in 2 of the Svalbard experiments could be due to either growth of an initially small population or to physiological induction. There is no obvious explanation for the isolated occurrence of induced mesophilic activity. However, the results in Fig. 2 illustrate that quite different conclusions about thermal characteristics can be reached depending on incubation time and emphasize the importance of monitoring time courses and keeping incubations times short in this type of experiment.

Investigations of the temperature dependence of oxygen respiration in sediments have so far only been reported from sediments from the temperate Aarhus Bay, Denmark, where a variation of both optimum temperature and $Q_{10}$ was observed between March and September in response to the seasonal temperature cycle (Thamdrup et al. 1998). Results of the 2 studies are compared in Fig. 4. The continuous variation in both parameters with in situ temperature demonstrates that ambient temperature has a strong influence on aerobic benthic communities. The $Q_{10}$ values for Aarhus Bay March were slightly but insignificantly higher than the mean $Q_{10}$ at Svalbard, and also optimum temperature ranges overlapped, though in Aarhus Bay a very broad optimum reached from 20 to $30^{\circ} \mathrm{C}$. Thus, the perennially cold Svalbard communities show no or only slight further adaptation to low temperature than that attained in winter in the temperate sediment.

The thermal adaptation of the communities to low temperature is expressed through lower optimum temperatures (though $T_{\text {opt }}$ is much higher than $T_{\text {in situ }}$ ) and in lower activation energies. Thus, at low temperature the cold-adapted communities retain a higher catalytic efficiency than the warm-adapted ones. However, the effect of the observed temperature adaptation on benthic respiration or carbon oxidation rates is difficult to quantify because comparison between sites is confounded by differences in substrate availability. Thus, the film of fresh diatoms included with the sediment from Weddewarden is a much better food source than

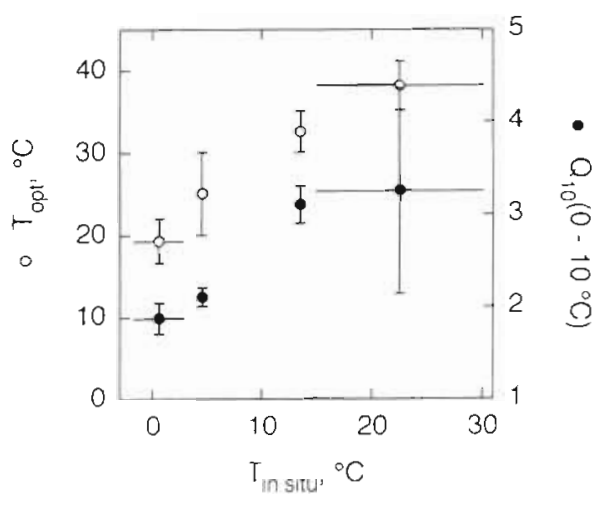

Fig. 4. Optimum temperature $\left(0\right.$, left axis) and $Q_{10}$ values ( $\bullet$, right axis) of oxygen respiration in sediments as a function of in situ temperature. Data are from the present study with all Svalbard sites pooled, and from Thamdrup et al. (1998). Horizontal bars indicate the span of in situ temperatures for the Svalbard sediments and the diel temperature range for the other sites. Vertical bars represent standard deviations for the present study and the span of duplicate experiments for the literature values 
what reaches the Svalbard sites at $>100 \mathrm{~m}$ depth, and it should contribute to the high activity at the temperate site. Also, among the Svalbard sites, differing sediment accumulation rates (Glud et al. unpubl.), and thereby substrate availability, were likely the main cause of the observed differences in oxygen consumption rates at in situ temperatures.

\section{Nitrogen mineralization}

The accumulation of DIN was included in this study as an alternative measure of mineralization, and to investigate whether the balance between $C$ and $N$ mineralization was affected by temperature. Assuming a 1:1 ratio of carbon oxidation to oxygen consumption, i.e. an average oxidation state of zero for the reacting carbon, rates of oxygen consumption corrected for the contribution of nitrification are equal to carbon mineralization rates, and the ratio of DIN production to oxygen consumption (Fig. 3) is equal to the N:C mineralization ratio. The stable average ratio of $-1: 7$ below $20^{\circ} \mathrm{C}$ corresponds closely to the decomposition of relatively fresh marine organic matter. Compared to the $\mathrm{N}$ :C ratio of the bulk sediment organic matter of $\sim 1: 10$ at all sites (D. E. Canfield pers. comm.) nitrogen was mineralized preferentially relative to carbon. Thus, temperature did not affect $\mathrm{C}$ and $\mathrm{N}$ mineralization differentially, and the mineralization ratios were similar to those typical for temperate sediments (e.g. Kristensen \& Blackburn 1987). By contrast, very low N:C mineralization ratios (mean 1:68) have previously been reported for sediments around Svalbard, including a site very near Sv5, and a preferential mineralization of carbon over nitrogen was implied (Blackburn et al. 1996). The present results show that the situation described by Blackburn and coworkers may not be typical for the region, and that it does not appear to be related particularly to the low temperatures of the Svalbard waters.

\section{Nitrification}

The oxidation of ammonia to nitrate involves 2 groups of organisms, the ammonia oxidizers that produce nitrite and the nitrite oxidizers that produce nitrate (Focht \& Verstraete 1977). Both groups are chemolithoautotrophs and are separate from the organoheterotrophic community that catalyzed the mineralization reactions discussed above. As nitrite concentrations were stable and very low during the incubations, the rate-limiting step for nitrification was between ammonia and nitrite. The temperature dependence observed was therefore that of the ammo- nia oxidizers, whereas the further oxidation to nitrate had as wide or wider temperature limits.

The half-saturation constant, $K_{M}$, for ammonia in benthic nitrifiers is highly variable (Henriksen \& Kemp 1988). Based on pore-water and flux measurements that indicated efficient ammonia oxidation to levels of $\leq 2 \mu \mathrm{M}$ (Glud et al. unpubl.), we expect a $K_{\mathrm{M}}$ for the Svalbard sediments well below the initial ammonia concentrations in our experiments. Even if nitrification was not quite saturated with ammonia, however, this would not significantly affect the temperature dependence as ammonia concentrations were similar over the temperature range in which nitrification was active.

Nitrification exhibited the strongest sensitivity to temperature of the investigated processes, with a very low optimum temperature and a steep decrease in rate above this in the Svalbard sediments. This suggested that the process was catalyzed by psychrophilic bacteria. Interestingly, however, all known nitrifying bacteria in culture are mesophiles with growth optima around $30^{\circ} \mathrm{C}$ (Bock \& Koops 1992, Koops \& Möller 1992). One ammonia oxidizer capable of growth down to $-5^{\circ} \mathrm{C}$ has been isolated from Alaskan waters (Jones et al. 1988) but even when acclimated to low temperatures, this organism had an optimum temperature for nitrification of $22^{\circ} \mathrm{C}$. Hence, it appears that nitrification in Svalbard sediments was catalyzed by organisms that have not been cultivated

Also, in comparison to other natural nitrifying communities, the temperature dependence in the Svalbard sediments exhibits the strongest adaptation to the cold so far reported. A correlation between the optimum temperature of nitrification and in situ temperature has been shown for soil communities (Malhi \& McGill 1982, Stark \& Firestone 1996). The lowest optimum, $20^{\circ} \mathrm{C}$, with very little activity below 5 and above $30^{\circ} \mathrm{C}$, was reported from a site with a mean annual air temperature of $2.5^{\circ} \mathrm{C}$ (Malhi \& McGill 1982). In temperate coastal sediments, the optimum temperature for nitrification remained $>22^{\circ} \mathrm{C}$ at in situ temperatures from $<3$ to $>12^{\circ} \mathrm{C}$ (Henriksen \& Kemp 1988)

With several subtidal coastal sediments, potential nitrification rates in the range 130 to $1610 \mathrm{nmol} \mathrm{cm} \mathrm{cm}^{-3}$ $\mathrm{d}^{-1}$ have been measured in slurries at $22^{\circ} \mathrm{C}$ in the presence of $500 \mu \mathrm{M}$ ammonia (Henriksen et al. 1981). Assuming a sediment density of $1.2 \mathrm{~g} \mathrm{~cm}^{-3}$ and a water content of $0.6 \mathrm{w} / \mathrm{w}$, this range translates to rates of 11 to $140 \mathrm{nmol} \mathrm{g}^{-1}$ dry wt $\mathrm{h}^{-1}$. In the Svalbard sediments, rates at in situ temperatures and natural ammonia concentrations ranged from 10 to $70 \mathrm{nmol} \mathrm{g}^{-1}$ dry wt $\mathrm{h}^{-1}$. Hence, the nitrifying communities in these sediments were as efficient as those in the much warmer incubations. This suggests that direct temperature effects on nitrification rates are fully compensated for by adaptations within the community. In agreement with this, 
benthic flux measurements and pore-water analyses at the Svalbard stations showed that a diffusive loss of ammonia from the sediments was efficiently prevented by nitrification in the oxic zone (Glud et al. unpubl.).

\section{Conclusion}

For all 3 processes quantified in this study, oxygen respiration, nitrogen mineralization, and nitrification. there were marked differences in temperature dependence between the permanently cold Svalbard sediments and the warm tidal sediment. The temperature characteristics of oxygen respiration from Svalbard were similar to those reported from a temperate coastal sediment in winter, whereas nitrification in the Arctic sediment exhibited the lowest optimum temperature so far reported for the process, suggesting the presence of unknown psychrophilic ammonia oxidizers.

Comparison of potential nitrification rates between Svalbard and temperate sediments showed that the catalytic efficiency of the nitrifying communities were comparable despite a $20^{\circ} \mathrm{C}$ difference in temperature. This suggests that at the community level, the process is constrained by factors that are not or only weakly temperature dependent. For oxygen respiration such a comparison was confounded by variations in the reactivity of organic matter between sites. For an accurate determination of the catalytic efficiency at different temperatures, an experimental system with a controlled input of organic matter would be required. Still, our observations support that low temperature does not cause qualitative shifts in patterns of aerobic benthic mineralization, including $C: N$ mineralization ratios, and that, because of thermal adaptation of the communities, mineralization rates in permanently cold sediments are not markedly depressed relative to temperate sites. In further support of this, a comparison of total benthic mineralization rates in the Svalbard sediments to those of several sites at similar water depth in temperate regions showed quite similar values (Glud et al. unpubl.), and also potential hydrolysis rates for polysaccharides were as high in the Svalbard sediments as at temperate sites (Arnosti et al, 1998).

Acknowledgements. We thank Don Canfield both for leading the Svalbard expedition and, together with the rest of the scientific party and the captain and crew of RV 'Jan Majen', for a successful and enjoyable cruise. We also thank Jens Sagemann for constructing the temperature gradient block.

\section{LITERATURE CITED}

Arnosti C, Sagemann J, Jørgensen BB, Thamdrup B (1998) Temperature dependence of microbial degradation of organic matter in marine sediments: polysaccharide hydrolysis, oxygen consumption, and sulfate reduction. Mar Ecol Prog Ser 165:59-70

Banta GT, Giblin AE, Hobbie JE, Tucker J (1995) Benthic respiration and nitrogen release in Buzzards Bay, Massachusetts. J Mar Res 53:107-135

Blackburn TH, Hall POJ, Hulth S, Landén A (1996) Organic$N$ loss by efflux and burial associated with a low efflux of inorganic $N$ and with nitrate assimilation in Arctic sediments (Svalbard, Norway). Mar Ecol Prog Ser 141: 283-293

Bock E, Koops HP (1992) The genus Nitrobacter and related genera. In: Balows A, Trüper HG, Dworkin M, Harder W, Schleifer $\mathrm{KH}$ (eds) The Prokaryotes, 2nd edn, Vol III. Springer-Verlag, New York, p 2302-2309

Braman RS, Hendrix SA (1989) Nanogram nitrite and nitrate determination in environmental and biological materials by vanadium(III) reduction with chemiluminescence detection. Analyt Chem 61:2715-2718

Christian RR, Wiebe WJ (1974) The effects of temperature upon the reproduction and respiration of a marine obligate psychrophile. Can J Microbiol 20:1341-1345

Eilertsen HC, Taasen JP, Weslawski JM (1989) Phytoplankton in the fjords of West Spitzbergen: physical environment and production in spring and summer. J Plankton Res 11: $1245-1260$

Focht DD, Verstraete W (1977) Biochemical ecology of nitrification and denitrification. Adv Microb Ecol 1:135-214

Grasshoff K, Ehrhardt M, Kremling K (1983) Methods of seawater analysis, 2nd edn. Verlag Chemie, Weinheim

Grebmeier JM, McRoy CP (1989) Pelagic-benthic coupling on the shelf of the northern Bering and Chukchi Seas. III. Benthic food supply and carbon cycling. Mar Ecol Prog Ser 53:79-91

Hall POJ, Aller RC (1992) Rapid small-volume flow injection analysis for $\Sigma \mathrm{CO}_{2}$ and $\mathrm{NH}_{4}{ }^{+}$in marine and freshwaters. Limnol Oceanogr 37:1113-1119

Harder W, Veldkamp H (1971) Competition of marine psychrophilic bacteria at low temperatures. Antonie Leeuwenhoek 37:51-63

Henriksen K, Hansen JI, Blackburn TH (1981) Rates of nitrification, distribution of nitrifying bacteria, and nitrate fluxes in different types of sediment from Danish waters. Mar Biol 61:299-304

Henriksen K, Kemp WM (1988) Nitrification in estuarine and coastal marine sediments. In: Blackburn TH, Sørensen J (eds) Nitrogen cycling in coastal marine environments. John Wiley and Sons, New York, p 207-249

Hulth S, Blackburn TH, Hall POJ (1994) Arctic sediments (Svalbard): consumption and microdistribution of oxygen. Mar Chem 46:293-316

Isaksen MF, Jergensen BB (1996) Adaptation of psychrophilic and psychrotrophic sulfate-reducing bacteria to permanently cold marine sediments. Appl Environ Microbiol 62: 408-414

Jones RD, Morita RY, Koops HP, Watson SW (1988) A new marine ammonium-oxidizing bacterium, Nitrosomonas cryotolerans sp. nov. Can J Microbiol 34:1122-1128

Jørgensen BB, Sørensen J (1.985) Seasonal cycles of $\mathrm{O}_{2}, \mathrm{NO}_{3}$ and $\mathrm{SO}_{4}{ }^{2-}$ reduction in estuarine sediments: the significance of an $\mathrm{NO}_{3}{ }^{-}$reduction maximum in spring. Mar Ecol Prog Ser 24:65-74

King D, Nedwell DB (1984) Changes in the nitrate-reducing community of an anaerobic saltmarsh sediment in response to seasonal selection by temperature. J Gen Mirrobiol 130:2935-2941

Koops HP, Möller UC (1992) The lithotrophic ammonia-oxidizing bacteria. In: Balows $\mathrm{A}$, Trüper $\mathrm{HG}$, Dworkin $\mathrm{M}$. 
Harder W, Schleifer KH (eds) The Prokaryotes, 2nd edn, Vol III. Springer, New York, p 2625-2637

Kristensen E, Blackburn TH (1987) The fate of organic carbon and nitrogen in experimental marine sediment systems: influence of bioturbation and anoxia. J Mar Res 45. 231-257

Li WKW, Dickie PM (1987) Temperature characteristics of photosynthetic and heterotrophic activities: seasonal var1ations in temperate microbial plankton. Appl Environ Microbiol 53:2282-2295

Mackin JE, Aller RC (1984) Ammonium adsorption in marine sediments. Limnol Oceanogr 29:250-257

Malhi SS, McGill WB (1982) Nitrification in three Alberta soils: effect of temperature, moisture and substrate concentration. Soil Biol Biochem 14:393-399

Morse JW (1991) Oxidation kinetics of sedimentary pyrite in seawater. Geochim Cosmochim Acta 55:3665-3667

Nedwell DB (1989) Benthic microbial activity in an Antarctic coastal sediment at Signy Island, South Orkney Islands. Estuar Coast Shelf Sci 28:507-516

Nedwell DB, Walker TR, Ellis-Evans JC, Clarke A (1993) Measurements of seasonal rates and annual budgets of organic carbon fluxes in an Antarctic coastal environment at Signy Island, South Orkney Islands, suggest a broad balance between production and decomposition. Appl Environ Microbiol 59:3989-3995

Pamatmat MM (1971) Oxygen consumption by the seabed VI. Seasonal cycle of chemical oxidation in Puget Sound Int Rev Ges Hydrobiol 56:769-793

Pomeroy LR, Deibel D (1986) Temperature regulation of bacterial activity during the spring bloom in Newfoundland coastal waters. Science 233:359-361

Pomeroy LR, Wiebe WJ, Deibel D, Thompson RJ, Rowe GT,

Editorial responsibility: Gary King,

Walpole, Maine, USA
Pakulski JD (1991) Bacterial responses to temperature and substrate concentration during the Newfoundland spring bloom. Mar Ecol Prog Ser 75:143-159

Ratkowsky DA, Lowry RK. McMeekin TA, Stokes AN, Chandler RE (1983) Model for bacterial culture growth rate throughout the entire biokinetic temperature range. J Bacteriol 154:1222-1226

Rivkin RB, Anderson MR, Lajzerowicz C (1996) Microbial processes in cold oceans. I. Relationships between temperature and bacterial growth rate. Aquat Microb Ecol 10: $243-254$

Sagemann J, Jørgensen BB, Greeff O (1998) Temperature dependence and rates of sulfate reduction in cold sediments of Svalbard, Arctic Ocean. Geomicrobiol J 15:83-98

Sieburth JM (1967) Seasonal selection of estuarine bacteria by water temperature. J Exp Mar Biol Ecol 1:98-121

Stark JM (1996) Modeling the temperature response of nitrification. Biogeochemistry 35:433-445

Stark JM, Firestone MK (1996) Kinetic characteristics of ammonium-oxidizer communities in a California oak woodland-annual grassland. Soil Biol Biochem 28: $1307-1317$

Thamdrup B, Hansen JW, Jørgensen BB (1998) Temperature dependence of oxygen respiration in a temperate coastal sediment. FEMS Microbiol Ecol 25:189-200

Westrich JT, Berner RA (1988) The effect of temperature on rates of sulfate reduction in marine sediments. Geomicrobiol J 6:99-117

Zhabina NN, Volkov IT (1978) A method of determination of various sulfur compounds in sea sediments and rocks. In: Krumbein WE (ed) Environmental biogeochemistry and geomicrobiology, Vol 3. Ann Arbor Science Publishers, Ann Arbor, p 735-746

Submitted: November 14, 1997; Accepted: February 25, 1998 Proofs received from author(s): June 12, 1998 